\title{
O efeito do treino da visão periférica no ataque de iniciados do futsal: um estudo na competição
}

\author{
Effect of peripheral vision training on the attack of beginner \\ indoor soccer players: a study during competition
}

Nelson Kautzner Marques Junior ${ }^{1}$

1 Universidade Castelo Branco. Mestrado em Ciência da Motricidade Humana. Rio de Janeiro, RJ. Brasil. 2008.

Orientador: Prof. Vernon Furtado da Silva

\begin{abstract}
Resumo - Este estudo foi inserido na Ciência da Motricidade Humana, na área de concentração da Dimensão Biofísica, na linha de pesquisa do Estudo dos Mecanismos e Processos da Aprendizagem e da Conduta Motora e no constructo epistemológico de explicação fenomênica. O objetivo deste estudo foi investigar o aprendizado do treino da visão periférica (TVP) e o efeito dessa sessão no ataque do futsal, levando em consideração, nas duas tarefas, (aprendizado e ataque) a hemisfericidade. Dez meninos com 10,4 $\pm 2,31$ anos, praticantes de futsal do Lar da Criança, foram divididos em grupo experimental $(\mathrm{GE}, \mathrm{n}=5)$ e grupo controle $(\mathrm{GC}, \mathrm{n}=5) \mathrm{com}$ hemisfericidade $(\mathrm{H})$ similar (GE com $80 \%$ de $\mathrm{H}$ esquerda (E) e $20 \%$ de $\mathrm{H}$ direita (D), GC com 60\% de HE e 40\% de HD). Foram praticadas nove sessões e depois um campeonato, mais seis sessões e depois outro campeonato. Todos os campeonatos foram filmados e depois analisados por scout. No grau da visão periférica no ataque a ANOVA two way revelou diferença significativa, onde foi evidenciado que o GE obteve aquisição do TVP. No grau das fases ofensivas, a ANOVA two way determinou diferença significativa, onde o GE foi melhor no início ofensivo e na construção do ataque, o GC foi superior na finalização do $1^{\circ}$ turno e o GE foi mais competente na finalização do $2^{\circ}$ turno. Em relação à quantidade de gols do GE e do GC, a ANOVA two way não estabeleceu diferença significativa. Quanto à freqüência e falta no treino, o teste " $\mathrm{t}$ " independente foi significativo $(\mathrm{p} \leq 0,05)$, o GE treinou mais. Conclui-se que parece que o GE a conseguiu aquisição do TVP e parece que o TVP otimizou o ataque dessa amostra.
\end{abstract}

Palavras-chave: Visão; Treinamento; Futebol; Aprendizado; Desempenho esportivo.

Abstract - This study was conducted within the context of Human Motor Skill Science, in the area of Biophysical Dimension and following the research line of the Study of Learning Mechanisms and Processes and of Motor Conduct within the epistemological construct of phenomenological explanation. The objective of this study was to investigate peripheral vision training (PVT) and its effect on attack runs during indoor soccer, taking into account dominant laterality (brain hemisphere function) in both learning speed and offensive skills. Ten beginner indoor soccer players aged $10.4 \pm 2.31$ years, from Lar da Criança Padre Franz Neumair, Ititioca, Niterói, Rio de Janeiro, Brazil, participated in the study. The boys were divided into an experimental group ( $E G, n=5)$ and a control group (CG, $n=5$ ) with similar dominant laterality (brain hemisphere function) $(H)$ (EG: $80 \%$ left $\mathrm{H}$ and $20 \%$ right $\mathrm{H}, \mathrm{CG}$ : $60 \%$ left $\mathrm{H}$ and $40 \%$ right $\mathrm{H}$ ). The players underwent nine training sessions, followed by a championship, and then six additional sessions, followed by a second championship. Each championship was filmed for scout video analysis. Two-way ANOVA revealed a significant difference in peripheral vision during offensive runs between $C G$ and $E G$, with marked acquisition of peripheral vision in EG. The quality of the attack runs was significant (two-way ANOVA). EG was the better team at the beginning of the attack runs and during attack development, whereas CG was better at attack finalization during the first championship. EG showed more competence in attack run finalization during the second championship. No significant difference in the number of goals scored was observed between the two groups (two-way ANOVA, $p>0.05$ ). The frequency of participation in the training sessions was significant (t-test for independent samples, $p \leq 0.05$ ), with EG attending more sessions. In conclusion, EG acquired peripheral vision, a finding suggesting that PVT improves the attack capacity of indoor soccer players.

Key words: Vision; Trainning; Soccer; Learning; Atletic performance. 